\title{
God and the Faithfulness of Paul
}

\author{
A Critical Examination of the Pauline Theology of N.T. Wright \\ Ed. by Christoph Heilig, J. Thomas Hewitt, and Michael F. Bird
}

[Gott und die Treue des Paulus. Eine kritische Untersuchung der paulinischen Theologie von N. T. Wright.]

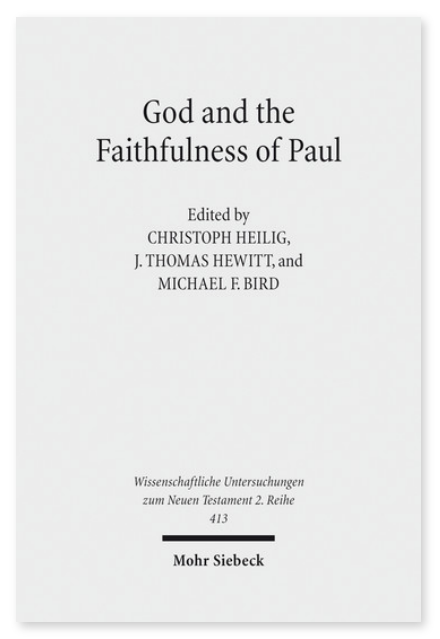

2016. VIII, 833 Seiten. WUNT II 413

ISBN 978-3-16-154247-3

DOI 10.1628/978-3-16-154247-3

eBook PDF $149,00 €$

ISBN 978-3-16-153851-3

fadengeheftete Broschur 149,00€
Veröffentlicht auf Englisch.

N. T. Wrights Werk Paul and the Faithfulness of God ist der Höhepunkt seiner langen, einflussreichen und oftmals kontroversen Karriere - eine richtungsweisende Untersuchung der Geschichte und des Denkens des Apostels Paulus, welche neue Ansätze für zahlreiche Bereiche neutestamentlicher Wissenschaft liefert. Der vorliegende Band vereint zahlreiche internationale Wissenschaftler, welche eine Bandbreite an Themen in Wrights Arbeit sorgfältig analysieren und kritisch prüfen: die Methodologie, die Bedeutung kontextueller Faktoren, exegetische Befunde und theologische Implikationen. Dadurch bringen die Autoren diese Aspekte von Paul and the Faithfulness of God in Verbindung mit dem aktuellen Stand der Forschung, sowohl im englischsprachigen als auch im deutschen Kontext. Der Band bietet damit sowohl eine kritische Auswertung von Wrights Leistung als auch einen hervorragenden Überblick über und eine Einführung in Themen, die derzeit innerhalb der Paulusforschung kontrovers diskutiert werden.

\section{Inhaltsübersicht}

\section{Part I: Prologue}

Michael F. Bird/Christoph Heilig and J. Thomas Hewitt: Introduction - Benjamin Schliesser: Paul and the Faithfulness of God among Pauline Theologies

\section{Part II: Methodological Issues}

Oda Wischmeyer: N. T. Wright's Biblical Hermeneutics Considered from A German Exegetical Perspective - Andreas Losch: Wright's Version of Critical Realism - Theresa Heilig and Christoph Heilig: Historical Methodology - Eve-Marie Becker: Wright's Paul and the Paul of Acts. A Critique of Pauline Exegesis - Inspired by Lukan Studies - Steve Moyise: Wright's Understanding of Paul's Use of Scripture - Joel R. White: N. T. Wright's Narrative Approach

\section{Part III: Contextual Issues}

James H. Charlesworth: Wright's Paradigm of Early Jewish Thought. Avoidance of Anachronisms? - Gregory E. Sterling: Wisdom or Foolishness? The Role of Philosophy in the Thought of Paul - Seyoon Kim: Paul and the Roman Empire - James Hanges: »A World of Shrines and Groves.« N. T. Wright and Paul among the Gods

\section{Part IV: Exegetical Issues}

Gregory Tatum: Law and Covenant in Paul and the Faithfulness of God - Sigurd Grindheim: Election and the Role of Israel Jörg Frey: Demythologizing Apocalyptic? On N. T. Wright's Paul, Apocalyptic Interpretation, and the Constraints of Construction - Aquila H. I. Lee: Messianism and Messiah in Paul. Christ as Jesus? - James D. G. Dunn: An Insider's Perspective on Wright's Version of the New Perspective on Paul - Peter Stuhlmacher: N. T. Wright's Understanding of Justification and Redemption - Torsten Jantsch: God and His Faithfulness in Paul. Aspects of the History of Research in Light of the Letter to the Romans - J. Thomas Hewitt and Matthew V. Novenson: Participationism and Messiah Christology in Paul - Larry W. Hurtado: YHWH's Return to Zion. A New Catalyst for Earliest High Christology? - John R. (Jack) Levison: The Spirit in Its Second Temple Context. An Exegetical Analysis of the Pneumatology of N. T. Wright - Richard H. Bell: Individual Eschatology - Volker Rabens: The Faithfulfness of God and Its Effects on Faithful Living: A Critical Analysis of Tom Wright's Faithfulness to Paul's Ethics

\section{Part V: Implications}

James Crossley and Katie Edwards: Paul and the Faithfulness of God as Postmodern Scholarship - Edith M. Humphrey: Bishop Wright. Sacramentality and the Role of Sacraments - Frank D. Macchia: The Spirit and God's Return to Indwell a People. A Systematic Theologian's Response to N. T. Wright's Reading of Paul's Pneumatology - Andrew McGowan: Ecclesiology as Ethnology. The Church in N. T. Wright's Paul and the Faithfulness of God - Eckhard J. Schnabel: Evangelism and the Mission of the Church - Sven Ensminger: Barth, Wright, and Theology

Part VI: Epilogue

N. T. Wright: The Challenge of Dialogue: A Partial and Preliminary Response

Christoph Heilig Born 1990; 2009-14 studied theology; 2013 Master of Letters in »Biblical Languages and Literature at St. Mary's College, University of St Andrews; since 2014 research at the University of Zurich (SNF Project).

J. Thomas Hewitt 2013 MLitt, University of St Andrews; 2018 PhD, University of Edinburgh; currently Kirby Laing Research Fellow in New Testament, School of Divinity, History, and Philosophy, University of Aberdeen. https://orcid.org/0000-0002-7339-0279

Michael F. Bird Born 1974; 2005 PhD from University of Queensland; 2005-09 New Testament Tutor at Highland Theological College; 2010-12 Lecturer in Theology at Crossway College; since 2013 Lecturer in Theology at Ridley College. 
Jetzt bestellen:

https://mohrsiebeck.com/buch/god-and-the-faithfulness-of-paul-9783161542473?no_cache=1

order@mohrsiebeck.com

Telefon: +49 (0)7071-923-17

Telefax: +49 (0)7071-51104

Mohr Siebeck GmbH \& Co. KG

Postfach 2040

D-72010 Tübingen

info@mohrsiebeck.com

Mohr Siebeck

www.mohrsiebeck.com 